\title{
Dynamics and growth estimates of planktonic protists during early spring in Lake Pavin, France
}

\author{
Jean-François Carrias ${ }^{*}$, Antoine Thouvenot, Christian Amblard, \\ Télesphore Sime-Ngando
}

Laboratoire de Biologie des Protistes, UMR CNRS, Université Blaise Pascal, Clermont-Ferrand II, 63177 Aubière Cedex, France

\begin{abstract}
The in situ growth rates of the dominant planktonic protists were estimated in Lake Pavin during early spring, from unfiltered (UF, i.e. raw) and fractionated $(<50$ and $<10 \mu \mathrm{m})$ water samples incubated in diffusion chambers. The early spring phytoplankton bloom was largely dominated by the plastidic dinoflagellate Gymnodinium uberrimum. Because they were not efficiently removed by filtration through the $10 \mu \mathrm{m}$ pore-size mesh, small ciliates (10 to $25 \mu \mathrm{m}$ in length: Urotricha spp., Balanion planctonicum and Strobilidium/Halteria) affected the growth rates of nanoflagellates in the $<10 \mu \mathrm{m}$ samples. Low or negative growth rates were also found for oligotrichs and tintinnids, which appeared to be very sensitive to manipulation and incubation. Except for the latter 2 taxa, species-specific theoretical growth rates (derived from cell volume and temperature) were close to those calculated from changes in natural abundances. Our results suggest that the small ciliate Urotricha may act as an essential trophic link between autotrophic nanoflagellates (ANF) and metazooplankton, and that large ciliates may be able to efficiently transfer energy between heterotrophic nanoflagellate (HNF) prey and metazooplankton grazers during early spring in Lake Pavin. Our experiments highlight the importance of taking into account each individual protist species, and of not considering flagellates and ciliates as being a uniform group in pelagic systems. Because of the great diversity of shape, size and flexibility of these cells, it is essential during fractionation experiments to confirm the effectiveness of the experimental protocols so as to identify possible artefacts and to obtain a more reliable estimate of the flows of material and energy in aquatic ecosystems.
\end{abstract}

KEY WORDS: Growth rates $\cdot$ Flagellates $\cdot$ Ciliates $\cdot$ Protists $\cdot$ Freshwaters $\cdot$ Lakes

Resale or republication not permitted without written consent of the publisher

\section{INTRODUCTION}

In recent years there have been many studies that have dealt with planktonic food chains and particularly the importance and role of the microbial loop in the functioning of pelagic lake ecosystems (Riemann \& Christoffersen 1993, Sanders \& Wickham 1993). In this context, the impact of predation by protozoans on the picoplankton communities during the period of thermal stratification has been assessed in several lakes (Sanders et al. 1989, Vaqué \& Pace 1992, Šimek et al. 1995, 1997, Carrias et al. 1996, Stabell 1996, Thouvenot et al. 1999), and it has been clearly shown that

\footnotetext{
*E-mail: j-francois.carrias@lbp.univ-bpclermont.fr
}

phagotrophic flagellates and ciliates play a fundamental role in the transfer of picoplankton production towards higher trophic levels (Stoecker \& Capuzzo 1990, Gifford 1991, Burns \& Gilbert 1993, Jürgens 1994, Wiackowski et al. 1994). Only a few studies have measured the in situ growth rates of protists (Taylor \& Johannsson 1991, Carrick et al. 1992, Macek et al. 1996, Weisse 1997) in order to evaluate the contribution of their production to the carbon flows. Moreover, most of these studies have been conducted during the period of thermal stratification and/or were focused on a single component of the protist communities. At this period, the large-sized Cladocera usually dominate the metazooplankton community in temperate lakes and exert a high predation pressure on all components of the microbial loop (Jürgens 1994). The growth rates of hetero- 
trophic protists estimated during thermal stratification are usually high and are generally temperature-related (Carrick et al. 1992, Jack \& Gilbert 1997, Weisse 1997). Protozoa could therefore account for a large proportion of heterotrophic production. There have been fewer estimates of growth rates and protozoan production during the spring overturn coinciding with the spring phytoplankton bloom (Hansen \& Christoffersen 1995). It is however during this period that the highest densities of protozoa are recorded in relatively unproductive temperate lakes (Beaver \& Crisman 1989, LaybournParry 1994). These peaks in density usually coincide with low biomasses of metazoan zooplankton (Weisse 1991), which suggests that protozoa could account for most of the secondary production in early spring.

The methods most commonly used for assessing in situ protozoan growth are based on the principle of size fractionation of predators and prey using nylon mesh screens. The samples are then incubated in the lake using bottles or diffusion chambers. Multiple regression equations that relate growth rates to ciliate species biovolume and temperature were proposed by Montagnes et al. (1988) and Müller \& Geller (1993), and are widely used to estimate ciliate growth rates. However, the specific growth rates of protists estimated by in situ incubation experiments are often lower than those derived from mathematical models or estimated under laboratory conditions (Taylor \& Johannsson 1991, Carrick et al. 1992, Hansen \& Christoffersen 1995, Macek et al. 1996, Weisse 1997). Although many hypotheses have been proposed to explain the very low growth rates measured in situ among certain protozoans (Taylor \& Johannsson 1991, Carrick et al. 1992, Macek et al. 1996, Jack \& Gilbert 1997), the effectiveness of the fractionation between prey and their predators and the specific effects of filtration on the densities of protists have never to our knowledge been tested. Within a planktonic community, protists may be highly diverse in terms of shape and size (Fenchel 1987), and most are known to be very sensitive to handling (Bloem et al. 1986, Sime-Ngando et al. 1990, Foissner \& Berger 1996).

In this study, we estimated the in situ growth rates of the most abundant protists during early spring in unfiltered (UF) and fractionated $(<50$ and $<10 \mu \mathrm{m})$ lake water incubated in diffusion chambers. These enclosures allowed exchanges of water and nutrients with the lake water. We evaluated the species-specific effects of size fractionation on the abundance of protists. Species-specific in situ growth of ciliates estimated in predator-free chambers were compared to theoretical growth rates (based on biovolume and temperature). The effects of predator removal (metazooplankton and large-sized ciliates) on protist growth rates were investigated in order to evaluate potential trophic interactions.

\section{MATERIALS AND METHODS}

Study site and sampling. The study was conducted in Lake Pavin, a meromictic and dimictic oligo-mesotrophic lake with partial overturns situated in the Massif Central of France. For more details on the morphometric characteristics of Lake Pavin, see Carrias et al. (1998a).

Water samples were collected weekly at $5 \mathrm{~m}$ depth from 16 March to 12 May 1998 with a 10 l-Van Dorn bottle from a central point in the lake. Water temperature and dissolved oxygen were measured with a YSY GRANT 3800 meter and probe at the same location. After a period of almost vertical uniformity of temperature throughout the water column $\left(3.8\right.$ to $\left.4.2^{\circ} \mathrm{C}\right)$ in March, the values gradually increased in April, reaching $8.8^{\circ} \mathrm{C}$ at $5 \mathrm{~m}$ depth at the end of the study. The dissolved oxygen concentrations at $5 \mathrm{~m}$ depth varied little, values ranging from 8.8 to $11.1 \mathrm{mg} \mathrm{l}^{-1}$.

Protozoan, algal and metazoan counts. Nanoflagellate samples $(50 \mathrm{ml})$ were fixed with $1 \%$ (final concentration) glutaraldehyde. Subsamples for counts were stained with primulin (Caron 1983) and collected onto $0.8 \mu \mathrm{m}$ pore-size black Nuclepore filters which were mounted within glass slides and coverslips using a non-fluorescent immersion oil. Preparations were made within $24 \mathrm{~h}$ after the sampling date and stored at $-25^{\circ} \mathrm{C}$ to minimise the loss of autofluorescence. Slides were examined at $\times 1250$ magnification by epifluorescence microscopy in a dark room using an Olympus HBS microscope equipped with a HB2-RFL epifluorescence illuminator, a HBO-100W mercury lamp and a 100/1.25 neoflar objective lens. Two sets of filters were used (UG-1, DM400, L 435: UV light and BP 490, DM 500, O 515: blue light) for autofluorescence and primulin analysis. A total of 300 to 600 nanoflagellates from each slide was counted on several transects (SD $<10 \%$ ). The pigmented dinoflagellate Gymnodinium uberrimum (mean length: $31.4 \mu \mathrm{m}$ ), which largely dominated the planktonic community during this study (see 'Results'), was counted at $\times 500$ magnification on these slides. For each cellular morphotype a mean biovolume was calculated assuming appropriate geometric configurations.

Subsamples of $200 \mathrm{ml}$ were collected for counts of ciliates, microflagellates and algae, and preserved with $2.5 \%$ (final concentration) mercuric chloride. Volumes of $50 \mathrm{ml}$ were settled for at least $24 \mathrm{~h}$ in plankton chambers and protists were counted under an inverted Leica microscope equipped with an image analyser and a personal computer at $\times 500$ magnification by scanning the whole chamber area. At least 200 ciliates, and 400 microflagellates and algae were counted for each sample, and were identified to genus or species level by consulting the works of Bourrelly $(1966,1968$, 
1970), Foissner \& Berger (1996) and Foissner et al. (1991, 1992, 1994, 1995). A supplementary objective (EF 63/0.85, ×785.5 magnification, Leica 15198580) was particularly useful for recognition of the smallest individuals. The dimensions of 20 to 40 individual cells for each taxon were measured at $\times 1250$ magnification by image analysis. Mean biovolume was estimated from appropriate geometric shapes.

Metazooplankton were counted by filtering duplicate $5 \mathrm{l}$ volumes of water through a $50 \mu \mathrm{m}$ pore-size mesh. Duplicate samples were preserved in a solution of formaldehyde ( $4 \%$ final concentration) with added sucrose to prevent the release of eggs and physical deformation (Prepas 1978). Counts were performed under a binocular microscope (Wild M3Z) in a Dolfuss chamber.

In situ growth estimates. Experiments were conducted on 5 dates to estimate in situ growth rates of both flagellates and ciliates and their mortality due to naturally occurring densities of potential consumers. Measurements were carried out in cubic diffusion chambers (dimensions $17 \times 17 \times 17 \mathrm{~cm}$ ) made of $6 \mathrm{~mm}$ thick plexiglass and having a volume of $4.9 \mathrm{l}$ each. All faces of each chamber were equipped with nylon mesh of $1 \mu \mathrm{m}$ pore size, accounting for $42 \%$ of the total surface area of a cube. Openings on 2 of the faces, fitted with stoppers, were used to fill and empty the chambers. Analysis of nitrogen and phosphorus concentrations, temperature, $\mathrm{pH}$ and oxygen, showed that the water quality was the same inside and outside of the chambers after $7 \mathrm{~h}$ of incubation (Thouvenot et al. 1999). The chambers employed in our study were similar to the chambers used by Müller \& Weisse (1994) and Weisse (1997).

A $~ 401$ volume of water was collected from a depth of $5 \mathrm{~m}$ in a large container. Diffusion chambers were used in duplicates and filled as follows: (1) with unfiltered water, (2) with water filtered through a set of 100 and $50 \mu \mathrm{m}$ mesh nylon screens to remove metazooplankton, and (3) with water filtered through a set of 100, 50 and $10 \mu \mathrm{m}$ mesh nylon screens to remove metazooplankton and ciliates. In preliminary experiments, 80 and $50 \mu \mathrm{m}$ mesh nylon screens were tested to collect metazooplankton. The smallest metazoa (i.e. some rotifers and copepodites) were only removed by filtration through a $50 \mu \mathrm{m}$ mesh nylon screen. Thus, we considered that all the metazooplankton were removed in $<50 \mu \mathrm{m}$ experimental samples.

Subsamples for nanoflagellate, microflagellate, algal and ciliate counts were collected at $t=0$ in unfiltered water and in the $<50$ and $<10 \mu \mathrm{m}$ filtrates, and in each diffusion chamber after $24 \mathrm{~h}$ of in situ incubation. Metazooplankton were collected at $t=0$ as described previously and at $t=24 \mathrm{~h}$ by filtering through a $50 \mu \mathrm{m}$ mesh nylon screen the whole of the remaining experi- mental samples (volume of water in the chamber - volume of the protist samples $=\sim 4.5$ l) from the duplicate unfiltered fractions. Differences in metazooplankton densities between $t=0$ and $t=24 \mathrm{~h}$ were negligible. The preservation and counts of planktonic communities were carried out as described previously.

Data analyses. From the initial subsamples, we tested the effects of the size fractionation on the abundance of the most abundant ciliates and flagellates for the 5 sampling dates. Differences in abundances between control (unfiltered fraction) and $<50$ or $<10 \mu \mathrm{m}$ treatments were tested by 2 -way ANOVA without replication. Time was considered as a second factor and abundances were log-transformed to homogenise variances.

Species-specific growth rates $\left(\mu, \mathrm{d}^{-1}\right)$ in each diffusion chamber were calculated from changes in cell numbers assuming exponential growth according to the equation: $\mu=\left(\ln N_{t}-\ln N_{0}\right) / t$ where $\mu$ is the apparent rate of population growth $\left(\mathrm{d}^{-1}\right), N_{0}$ and $N_{t}$ are the initial and final abundances, and $t$ is the duration of incubation. The effects of metazooplankton, time and their interactions on ciliate and flagellate growth rates were tested using 2-way ANOVA with replication. For this analysis, we compared species-specific growth rates in the $<50 \mu \mathrm{m}$ relative to the unfiltered fraction. A similar analysis was done to test the effect of largesized ciliates on nanoflagellates (ANF and HNF) and small ciliates by comparing growth rates in the $<10$ relative to the $<50 \mu \mathrm{m}$ fraction. MINITAB 12 was used for all statistical analyses.

Ciliate growth estimates were compared with theoretical (maximum) growth rates derived from the following equations:

$$
\begin{gathered}
\ln \mu_{\max }=0.1438 \ln T-0.3285 \ln \left(V \times 10^{-3}\right)-1.3815 \\
\text { (Montagnes et al. 1988) }
\end{gathered}
$$

and $\ln \mu_{\max }=1.52 \ln T-0.27 \ln V-1.44$

(Müller \& Geller 1993)

where $\mu_{\text {max }}$ is the maximum intrinsic growth rate $\left(\mathrm{d}^{-1}\right)$, $V$ is the ciliate biovolume (live, ${\mu m^{3}}^{3}$ ) and $T$ is the temperature. For these comparisons, biovolumes of fixed ciliates were multiplied by a factor of 1.4 for correction of shrinkage due to fixatives (Müller \& Geller 1993).

\section{RESULTS}

\section{Dynamics of algae, nanoflagellates, ciliates and metazooplankton}

The spring phytoplankton bloom was largely dominated by the plastidic Gymnodinium uberrimum (identified to species level on live specimens by Professor J.-P. Mignot), which reached a maximum density of 320.0 
cells ml ${ }^{-1}$ in early April (Fig. 1A). Other dinoflagellates, Peridinium willei, a common species in Lake Pavin, and a small unidentified Peridinium reached very low densities. During April, the densities of dinoflagellates decreased to $<10$ cells ml $^{-1}$ at the end of our study (Fig. 1A).
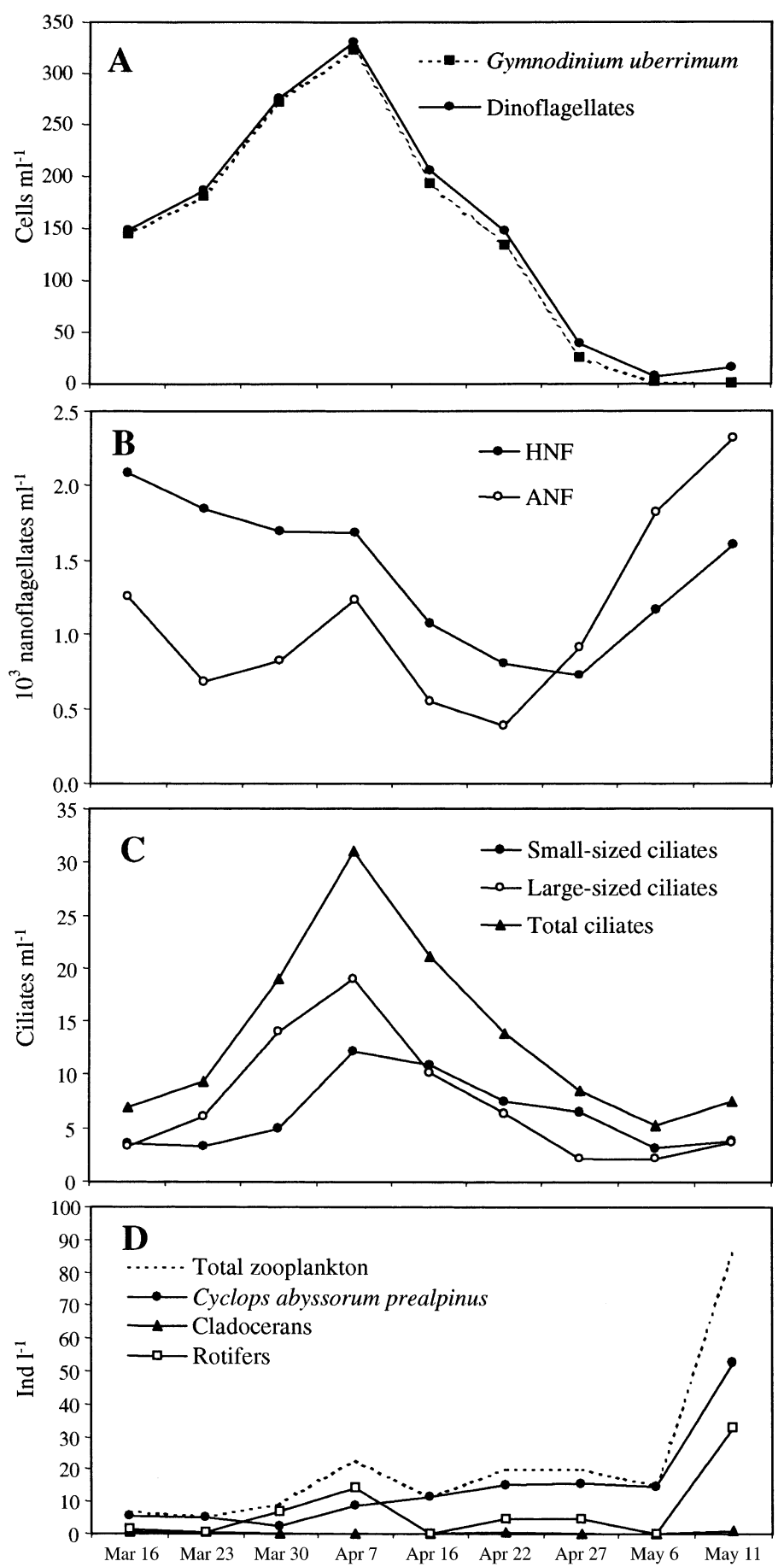

Fig. 1. Temporal changes in the abundance of (A) dinoflagellates, (B) nanoflagellates, (C) ciliates and (D) metazooplankton at $5 \mathrm{~m}$ depth in Lake Pavin
These large-size flagellates accounted for 67 to $82 \%$ of the phytoplankton biomass (data not shown). Other significant phytoplanktonic taxa were large-sized diatoms (Aulacoseira italica and Asterionella formosa) and the small chlorophyte Ankistrodesmus convolutus.

The highest densities $\left(1.6\right.$ and $2.0 \times 10^{3}$ cells ml$^{-1}$ ) of HNF were recorded at the start and at the end of our study (Fig. 1B). The lowest values $\left(0.8 \times 10^{3} \mathrm{cells} \mathrm{ml}^{-1}\right)$ occurred at the end of April and coincided with a change in the composition of the community. Katablepharids (6 to $9 \mu \mathrm{m}$ in length) replaced small-size colourless chrysomonads after this period. Choanoflagellates accounted for 2 to $30 \%$ of HNF and their proportion increased throughout the study. The highest density of ANF was recorded at the end of the study (Fig. 1B). This corresponded to the development of Chrysidalis peritaphrena, a very common species in Lake Pavin (Carrias et al. 1996, 1998b).

Temporal changes in the density of ciliates were similar to those of dinoflagellates (Fig. 1A,C). The highest density ( 31.0 cells ml $\left.{ }^{-1}\right)$ was reached in early April and the values then decreased until the end of the study. Prostomatids dominated in terms of numbers throughout the study (Fig. 2), accounting for 33 to $66 \%$ (mean $=45 \%$ ) of total ciliate abundance. Small Urotricha occurred in all samples and accounted for most of the prostomatids. Balanion planctonicum only occurred occasionally, whereas Urotricha pelagica was only recorded in the first half of the study. Oligotrichs (11 to $55 \%$ of total abundance, mean $=31 \%$ ) were represented by small-size species (Strobilidium sp. and Halteria sp., 16 to $20 \mu \mathrm{m}$ in length) and by Strombidium viride which became much more abundant after the end of April (Fig. 2). In contrast, tintinnids, which accounted for $30 \%$ of ciliates in March, decreased with

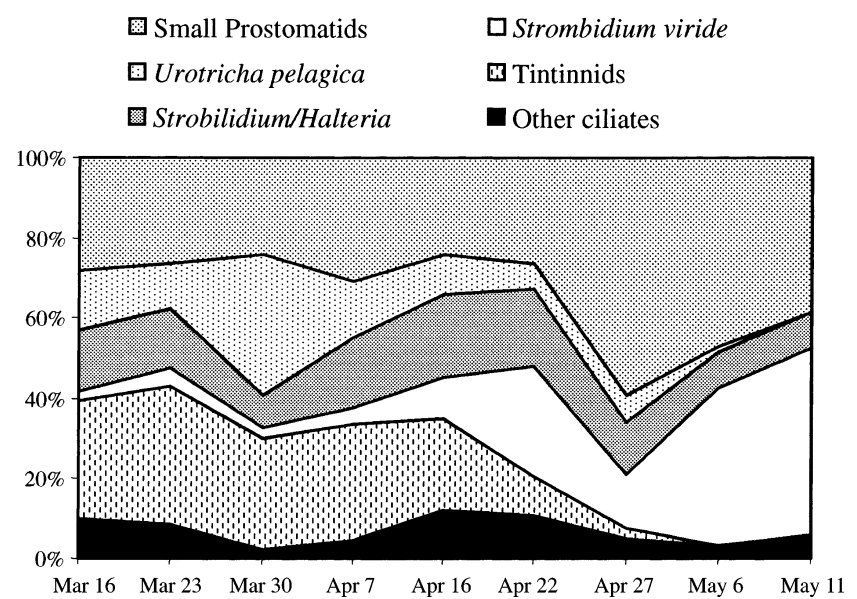

Fig. 2. Temporal changes in the relative abundance of ciliate taxa during early spring in Lake Pavin 
increasing temperatures. Other ciliates $(<12 \%$ of total ciliate abundance) included Colpoda sp., scuticociliates and small haptorids (Askenasia and Mesodinium).

Except at the end of our study, the metazooplankton density was low (<20 ind. $1^{-1}$; Fig. 1D). The cyclopoid Cyclops abyssorum prealpinus was the dominant species, occurring in all samples. Rotifers were found at very low density ( $<10$ ind. $\mathrm{l}^{-1}$ on most dates) and cladocerans were negligible $\left(<1\right.$ ind. $\left.\mathrm{l}^{-1}\right)$.

\section{Size fractionation of the dominant flagellates and ciliates}

Neither the $<10$ nor the $<50 \mu \mathrm{m}$ treatments significantly affected the densities of nanoflagellates (HNF and ANF) and small-sized ciliates (small Urotricha spp., Balanion planctonicum, Strobilidium sp. and Halteria sp.). The $<50 \mu \mathrm{m}$ treatment had no significant effect on the abundance of Gymnodinium. On average $65 \%$ of these cells were removed by the $<10 \mu \mathrm{m}$ treatment but differences in abundances between control and treatment were marginally significant (ANOVA, $\mathrm{p}=0.08)$. Cell removal for Urotricha pelagica and Colpoda sp. was significant for the $<10 \mu \mathrm{m}$ treatment only (U. pelagica, $\mathrm{p}=0.03$; Colpoda sp., $\mathrm{p}=0.04$ ) . On average $80 \%$ of these cells were removed. Abundances of Strombidium viride and tintinnids were significantly lower in the $<50$ ( $S$. viride, $\mathrm{p}=0.03$; tintinnids, $\mathrm{p}=0.04$ ) and $<10 \mu \mathrm{m}$ filtrates $(S$. viride, $\mathrm{p}=0.01$; tintinnids, $\mathrm{p}=$ 0.001 ) compared to the control. Between 70 and $98 \%$ of these ciliate cells were removed by the $<50$ and $<10 \mu \mathrm{m}$ treatments, respectively.

\section{In situ growth estimates}

Growth rates of the most abundant protists during this study are shown in Fig. 3. On most dates, largesize protists (Gymnodinium uberrimum, Strombidium viride, tintinnids, Urotricha pelagica and Colpoda sp.) were not present in sufficient numbers in the $<10 \mu \mathrm{m}$ filtrate to estimate growth rates. Due to their low densities and their similar size, data on small oligotrichous ciliates (Strobilidium sp. and Halteria sp.) were pooled.

HNF showed positive growth at the end of the study with rates ranging from 0.26 to $0.65 \mathrm{~d}^{-1}$ in the $<10$ and $<50 \mu \mathrm{m}$ fractions. Values in the $<50 \mu \mathrm{m}$ filtrates were not significantly different compared to the fractions with metazooplankton (Table 1). In contrast, HNF growth increased significantly in the $<10$ relative to the $<50 \mu \mathrm{m}$ filtrates (Table 2). No clear pattern was observed for ANF growth rates (Fig. 3) and differences between treatments were not significant (Tables $1 \& 2$ ). For all treatments, values ranged from -0.5 to $0.7 \mathrm{~d}^{-1}$. On average ANF growth estimates tended to be greater with metazooplankton $\left(0.2 \pm 0.4 \mathrm{~d}^{-1}\right)$ than in the $<50$ and $<10 \mu \mathrm{m}$ filtrates $\left(0.1 \pm 0.4\right.$ and $\left.0.0 \pm 0.3 \mathrm{~d}^{-1}\right)$. Positive growth of Gymnodinium uberrimum was noted in the unfiltered fraction during peak density only. Growth rates of small Urotricha spp. in the $<50$ and $<10 \mu \mathrm{m}$ fractions were never negative, rang-

Table 1. Cell length and mean volume of the major protists during early spring in Lake Pavin determined from fixed samples in the control and 2-way ANOVA results for effects of zooplankton removal and time on species-specific growth rates. For tintinnids, dimensions are length and width of the lorica

\begin{tabular}{|c|c|c|c|c|c|c|c|c|c|}
\hline & \multicolumn{2}{|c|}{$\begin{array}{l}\text { Length } \\
(\mu \mathrm{m})\end{array}$} & \multirow{2}{*}{$\begin{array}{c}\text { Mean } \\
\text { volume } \\
\left(\mu \mathrm{m}^{3}\right)\end{array}$} & \multicolumn{2}{|c|}{$\begin{array}{c}\text { Treatment } \\
(<50 \mu \mathrm{m} \text { relative to UF })\end{array}$} & \multicolumn{2}{|c|}{ Time } & \multicolumn{2}{|c|}{$\begin{array}{l}\text { Time } \times \\
\text { Treatment }\end{array}$} \\
\hline & Mean & Range & & $F$ & $\mathrm{p}$ & $F$ & $\mathrm{p}$ & $F$ & $\mathrm{p}$ \\
\hline HNF & 5.0 & $2.5-18.0$ & 38 & 0.01 & 0.91 & 19.25 & $<0.001$ & 13.66 & $<0.001$ \\
\hline ANF & 6.5 & $3.3-9.8$ & 32 & 1.54 & 0.24 & 15.44 & $<0.001$ & 3.41 & 0.05 \\
\hline Gymnodinium uberrimum & 31.4 & $28.7-34.1$ & $9.3 \times 10^{3}$ & 0.03 & 0.87 & 1.91 & 0.22 & 4.09 & 0.07 \\
\hline Small Urotricha spp. & 19.2 & $16.1-22.2$ & $1.8 \times 10^{3}$ & 4.42 & 0.06 & 17.56 & $<0.001$ & 2.48 & 0.11 \\
\hline Balanion planctonicum & 12.8 & $11.4-14.9$ & $0.7 \times 10^{3}$ & 0.04 & 0.85 & 3.62 & 0.09 & 0.64 & 0.55 \\
\hline Urotricha pelagica & 40.3 & $32.2-51.2$ & $28.7 \times 10^{3}$ & 5.29 & 0.06 & 9.96 & 0.01 & 6.45 & 0.03 \\
\hline Strobilidium/Halteria & 18.1 & $15.6-20.1$ & $1.3 \times 10^{3}$ & 0.01 & 0.92 & 6.33 & $<0.01$ & 0.44 & 0.77 \\
\hline Strombidium viride & 44.0 & $41.6-55.9$ & $10.8 \times 10^{3}$ & 3.05 & 0.15 & 0.04 & 0.84 & 1.32 & 0.31 \\
\hline $\begin{array}{l}\text { Tintinnids: } \\
\text { Lorica } \\
\text { Cells }\end{array}$ & $\begin{array}{l}77.2 \\
39.2\end{array}$ & $\begin{array}{l}66.0-104.0 \\
31.1-44.6\end{array}$ & $\begin{array}{r}17.2 \times 10^{3} \\
4.5 \times 10^{3}\end{array}$ & 5.89 & 0.05 & 44.01 & $<0.001$ & 2.37 & 0.17 \\
\hline Colpoda sp. & 38.8 & $36.0-42.2$ & $13.2 \times 10^{3}$ & 7.35 & 0.03 & 17.08 & $<0.01$ & 0.97 & 0.43 \\
\hline Large ciliates & - & - & - & 9.81 & $<0.01$ & 3.49 & 0.05 & 4.16 & 0.03 \\
\hline Small ciliates & - & - & - & 1.06 & 0.32 & 9.11 & $<0.01$ & 2.47 & 0.11 \\
\hline
\end{tabular}



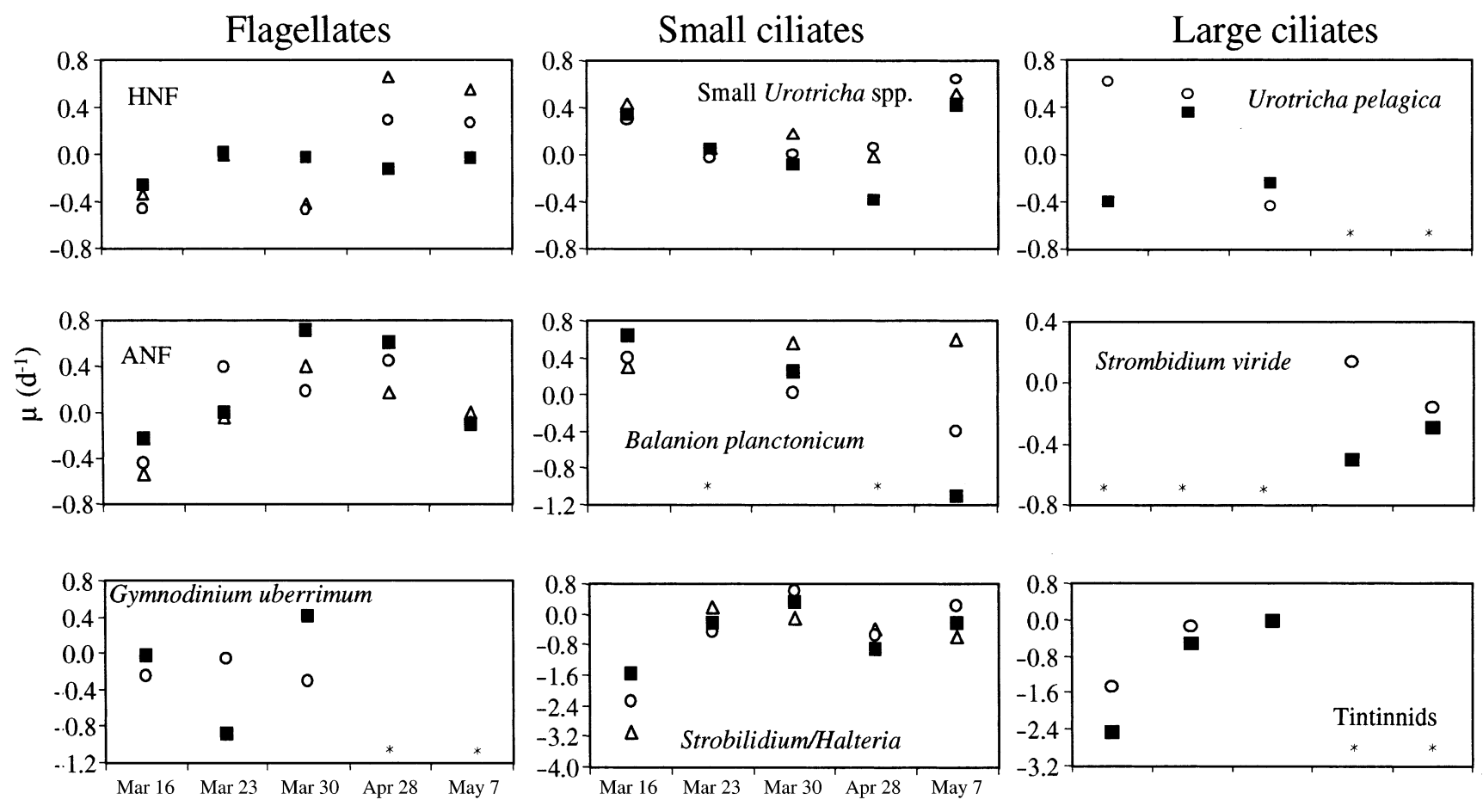

$$
\begin{aligned}
& \square \text { UF } \\
& \circ<50 \mu \mathrm{m} \\
& \Delta<10 \mu \mathrm{m}
\end{aligned}
$$

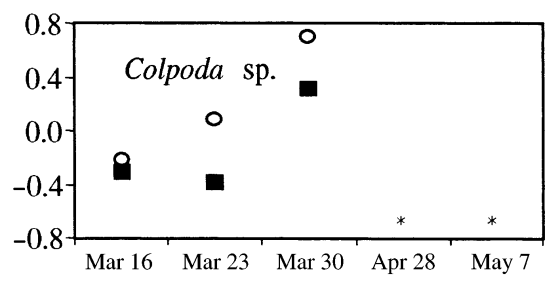

Fig. 3. In situ growth rates of dominant planktonic protists in unfiltered (UF) and fractionated ( $<50$ and $<10 \mu \mathrm{m})$ lake water determined from diffusion chamber experiments. Values are means of 2 replicates. ${ }^{*}$ Not present in sufficient numbers to estimate growth rates

ing from $\sim 0.0$ to $0.64 \mathrm{~d}^{-1}$. On average values increased with size fractionation $(0.07 \pm 0.30,0.19 \pm 0.28$ and 0.23 $\pm 0.20 \mathrm{~d}^{-1}$ in the $\mathrm{UF}_{1}<50$ and $<10 \mu \mathrm{m}$ treatments, respectively) and differences between the $<50$ and $<10 \mu \mathrm{m}$ treatments were significant at the $10 \%$ level (Table 1). Although no significant differences between treatments were observed for Balanion planctonicum (Tables $1 \& 2$ ), values were always positive in the $<10 \mu \mathrm{m}$ filtrates (range: 0.31 to 0.60 , mean: $0.49 \mathrm{~d}^{-1}$ ). Several negative values were found for the small oligotrichs Strobilidium/Halteria with little variations between fractions. Negative values were also recorded for largesize ciliates and especially for Strombidium viride and tintinnids.

On most dates growth rates of large-sized ciliates were higher in the $<50 \mu \mathrm{m}$ fraction than in the unfiltered water (Fig. 3). The increase of growth in the $50 \mu \mathrm{m}$ treatment was significant at the $5 \%$ level for Colpoda sp. and marginally significant $(0.05<\mathrm{p}<0.1)$ for Urotricha pelagica and tintinnids (Table 1). If the ciliate abundances are pooled into large (Strombidium viride, tintinnids, Urotricha pelagica and Colpoda sp.) and small (small Urotricha spp., Balanion planctonicum and Strobilidium/Halteria) ciliates, the increase in the growth rate of large cells in the metazooplankton-free fractions was significant at the $1 \%$ level (Table 1).

Small prostomatid (small Urotricha spp., Balanion planctonicum) growth rates, estimated from changes in abundance, were close to the theoretical ones calculated from biovolume and ambient temperature according both to Müller \& Geller (1993) and to Montagnes et al. (1988) (Fig. 4). Measured values were lower than predicted rates for oligotrichs (Strobilidium/ Halteria, Strombidium viride) and tintinnids. A wide range of variation was observed for small oligotrichs and tintinnids for natural estimates. The range of variation in growth rates of Urotricha pelagica and of Colpoda sp. was also wider for the estimated values than for those derived from biovolumes and tempera- 
Table 2. Two-way ANOVA results for effects of metazooplankton and large size ciliate removal and time on nanoflagellate and small ciliate growth rates

\begin{tabular}{|c|c|c|c|c|c|c|}
\hline & \multicolumn{2}{|c|}{$\begin{array}{c}\text { Treatment } \\
(<10 \text { relative to }<50)\end{array}$} & \multicolumn{2}{|c|}{ Time } & \multicolumn{2}{|c|}{ Time $\times$ Treatment } \\
\hline & $F$ & $\mathrm{p}$ & $F$ & $\mathrm{p}$ & $F$ & $\mathrm{p}$ \\
\hline HNF & 8.57 & 0.01 & 45.63 & $<0.001$ & 1.41 & 0.30 \\
\hline ANF & 0.66 & 0.43 & 6.44 & $<0.01$ & 1.01 & 0.44 \\
\hline Small Urotricha spp. & 0.41 & 0.53 & 11.06 & $<0.01$ & 0.80 & 0.55 \\
\hline Balanion planctonicum & 2.34 & 0.17 & 0.23 & 0.80 & 0.97 & 0.43 \\
\hline Strobilidium/Halteria & 1.06 & 0.32 & 12.12 & $<0.01$ & 0.97 & 0.46 \\
\hline Small ciliates & 0.49 & 0.49 & 10.15 & $<0.01$ & 0.34 & 0.84 \\
\hline
\end{tabular}

ture, and the highest values measured exceeded those calculated by the equations. Nevertheless, with the exception of oligotrichs and tintinnids, the mean growth rates calculated by the 3 methods were very close for all taxa (Fig. 4), ranging from 0.3 to $0.5 \mathrm{~d}^{-1}$.

\section{DISCUSSION}

\section{Early spring dynamics of planktonic communities}

Although the planktonic communities of Lake Pavin have been the subject of many studies in the last $10 \mathrm{yr}$ (Amblard \& Bourdier 1990, Amblard et al. 1992, Car- rias et al. 1996, 1998a,b, Quiblier-Lloberas et al. 1996), the plankton composition and population dynamics in early spring remain poorly known. Most previous studies started at the spring overturn, and it is generally admitted that the spring phytoplankton bloom is largely dominated by the diatom Aulacoseira italica (Amblard \& Bourdier 1990, Amblard et al. 1992). The present study started just after the melting of the ice cover when the temperature of most of the water column was $3.8^{\circ} \mathrm{C}$. At this period, the phytoplankton biomass was largely dominated by the dinoflagellate Gymnodinium uberrimum and it was only from the end of April that large-size diatoms (Aulacoseira italica and Asterionella formosa) developed and became dominant during May (Amblard \& Bourdier 1992, Carrias et al. 1998a).

With the exception of tintinnids, which developed very early during the spring isothermal period, all the ciliate and nanoflagellate taxa occurring have been reported during previous studies in the spring (Carrias et al. 1996, 1998a,b). However, the peak of ciliates occurred earlier than was suggested by previous studies and coincided with a decrease in the densities of

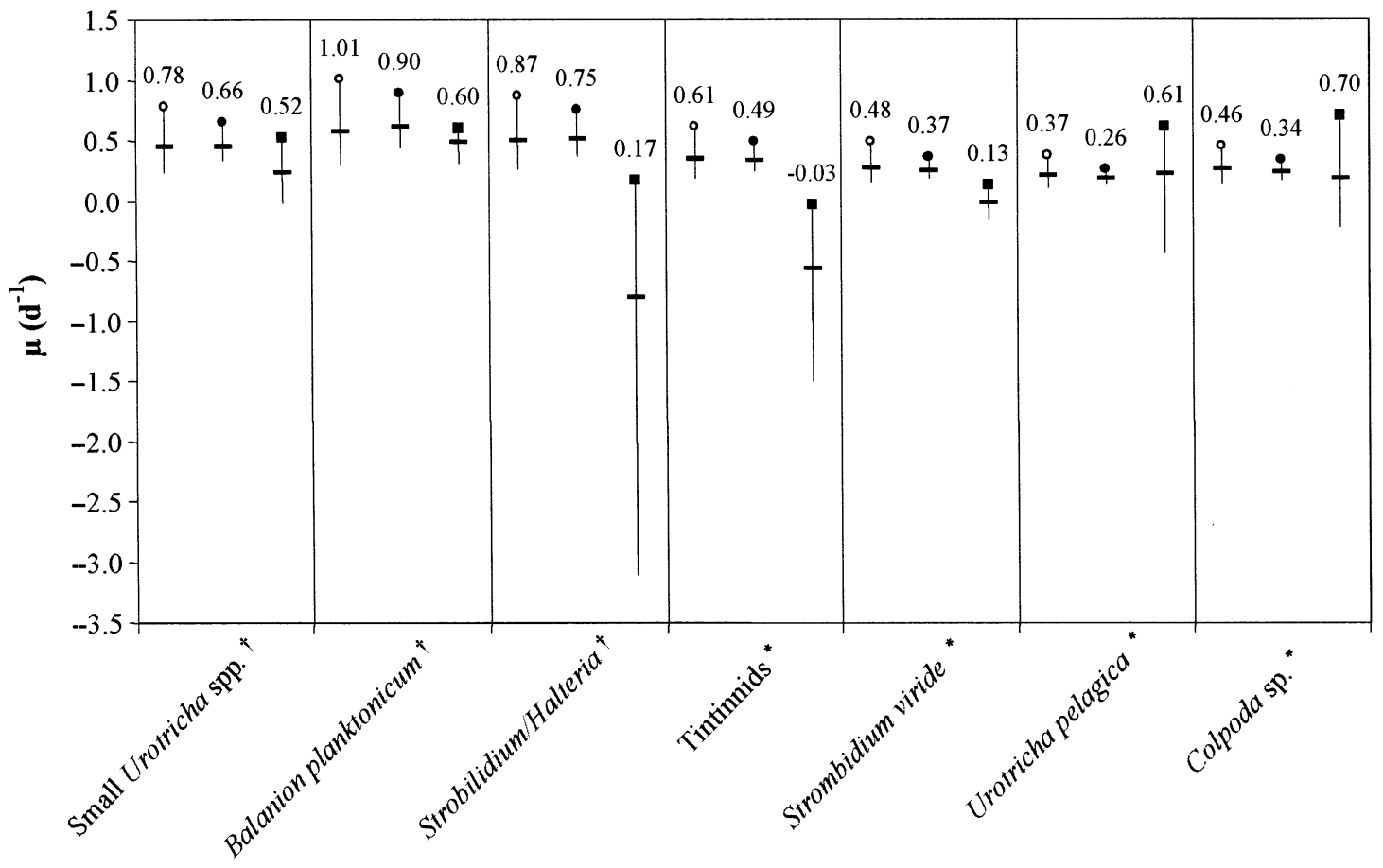

Fig. 4. Ranges of species-specific growth rates of most abundant ciliates derived from biovolume and temperature according to

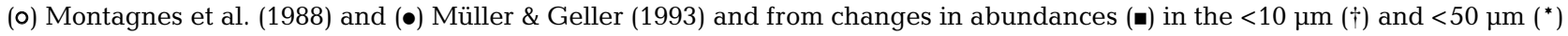
fractions. Horizontal bar shows means value of 2 replicates 
nanoflagellates, suggesting that there is probably a predator-prey interaction between these 2 communities. The metazooplankton densities were very low throughout most of this study and no net increase in metazooplankton was observed in April, whereas there was a very clear decrease in dinoflagellates and ciliates. It is unlikely that the metazooplankton densities were underestimated in this period because of the strong mixing recorded throughout the study. High densities of Cyclops abyssorum prealpinus and of rotifers were recorded at the end of the study and were followed by an increase in HNF and ANF in the water column. This suggests that the development of metazooplankton in the spring was more related to the availability of nanoplanktonic prey than to larger size prey such as dinoflagellates and ciliates. Our experiments in diffusion chambers support this hypothesis (see below).

\section{Effects of size-fractionation on the abundance of the most abundant planktonic protists}

In assessing in situ protozoan growth, size fractionation of prey and predators using mesh nylon screens has been used in many studies (Nagata 1988, Taylor \& Johannsson 1991, Carrick et al. 1992, Chrzanowski \& Šimek 1993, Hansen \& Christoffersen 1995, Macek et al. 1996, Weisse 1997, Jürgens et al. 1999, Šimek et al. 2000). However, the effectiveness of the fractionation was never tested in any of these studies, and it is therefore likely that the growth rates of some protozoans were underestimated because of the presence of predators in the filtrates incubated in situ, as has been suggested by Carrick et al. (1992). This study showed that the $10 \mu \mathrm{m}$ treatment did not remove any small ciliates (length: 11.4 to 22.2 ; width: 9.6 to 16.6 ) as their abundances in the control were similar to those in the $<10 \mu \mathrm{m}$ fraction. The pore size of the filters that have been used to separate the nanoflagellates from their predators has varied from 3 to $25 \mu \mathrm{m}$ (Nagata 1988, Carrick et al. 1992, Chrzanowski \& Šimek 1993, Weisse 1997) and, to our knowledge, neither the presence of predators in these filtrates nor the possible removal of some taxa of nanoflagellates by the treatment have been confirmed. Similarly, although the abundance of large ciliates and Gymnodinium in the $<10 \mu \mathrm{m}$ fraction were much lower than in the controls, the separation was never $100 \%$ effective and, sometimes, significant densities of some taxa of ciliates (Urotricha pelagica, Colpoda sp.) that are potentially predators of nanoflagellates were recorded in the $<10 \mu \mathrm{m}$ filtrates. It is therefore clear that the estimates of nanoflagellate growth rates in this study were underestimated because of the presence of small-sized ciliates that are thought to be important consumers of nanoflagellates (Rassoulzadegan et al. 1988, Weisse et al. 1990, Müller 1991, Weisse 1991). These results clearly demonstrate that protists have a very great ability to become deformed and pass through apertures smaller than their apparent size and that the pore size of the filters is undoubtedly irregular (Stockner et al. 1990). In the light of our results, it would also appear to be difficult to effectively separate large-sized ciliates from metazoan zooplankton. The filtration through $50 \mu \mathrm{m}$ frequently led to losses of all taxa of large-sized ciliates. This was particularly the case for Strombidium viride and tintinnids whose densities in the $<50 \mu \mathrm{m}$ filtrate were significantly lower than in the control. The growth rates of nanoflagellates in the $<10 \mu \mathrm{m}$ fraction more closely represent gross growth rates rather than net growth rates (e.g. growth rates that are not reduced by any external loss factors) whereas those of large-sized ciliates in the fraction $<50 \mu \mathrm{m}$ and smallsized ciliates in the $<10 \mu \mathrm{m}$ fraction are close to net growth.

\section{Evidence of sensitivity to incubation of some taxa}

Although the presence of predators must be taken into account in such experiments, it would however appear that even in the absence of predators, some taxa show a great sensitivity to incubation which often leads to measurements of negative growth rates. For example, the estimated values for Gymnodinium uberrimum were $\leq 0$ for most of the experimental samples (Fig. 3), whereas at the same time there was an increase in the density of these cells in the lake (Fig. 1A). Very large decreases in the densities of small-size oligotrichs (Strobilidium/Halteria) were also recorded in the diffusion chambers. The growth rates of these organisms in the $<10 \mu \mathrm{m}$ fraction were always negative whereas those of small prostomatids were always $\geq 0$ (Fig. 3) and close to the values estimated from the equations (Fig. 4). Similarly, the values estimated for Strombidium viride and tintinnids were nearly all negative and much lower than those of the models, which confirms the very great sensitivity and fragility of these cells (Sime-Ngando et al. 1990).

With the exception of the growth rates of oligotrichs and tintinnids, the mean values of the growth rates of other ciliates were very close to the mean values given by the models (Fig. 4), which suggests that these ciliates were unaffected by the experimental protocol during the study. This also highlights the absence of any prey limitation among protozoa in our filtrates, as the theoretical growth rates represent the maximum rates, i.e. when food concentration is over the limiting level (Montagnes et al. 1988, Müller \& Geller 1993). 
These results contrast with other published data (Table 3) where the measured growth rates are frequently all lower than those calculated by the equations (Taylor \& Johannsson 1991, Carrick et al. 1992, Hansen \& Christoffersen 1995, Macek et al. 1996, Montagnes 1996). However, in all the studies cited in Table 3, no test was conducted on the effectiveness of the fractionation between predators and prey, and the ciliate growth rates could have been underestimated because predators were present. Moreover, most of the ciliate growth rates reported in the literature (Table 3) have been measured during the period of thermal stratification, at much higher temperature values than those in our study, and it is evident that at low temperatures the estimated growth rates are much closer to those calcu- lated by the models (Müller \& Geller 1993). Finally, nutrient limitation in unproductive lakes is much more pronounced during the period of thermal stratification than during the spring phytoplankton bloom and this limitation probably restricts the growth of the microzooplankton and could also explain these differences.

\section{Comparison of growth estimates in unfiltered and fractionated lake water}

Despite the various artefacts described above, our results suggest that there are different trophic relations between nanoflagellates and ciliates than between protozoa and metazoan zooplankton. Thus, the

Table 3. In situ growth rates of planktonic ciliates (oligotrichs and prostomatids are considered only) estimated in fractionated lake water. -: not indicated

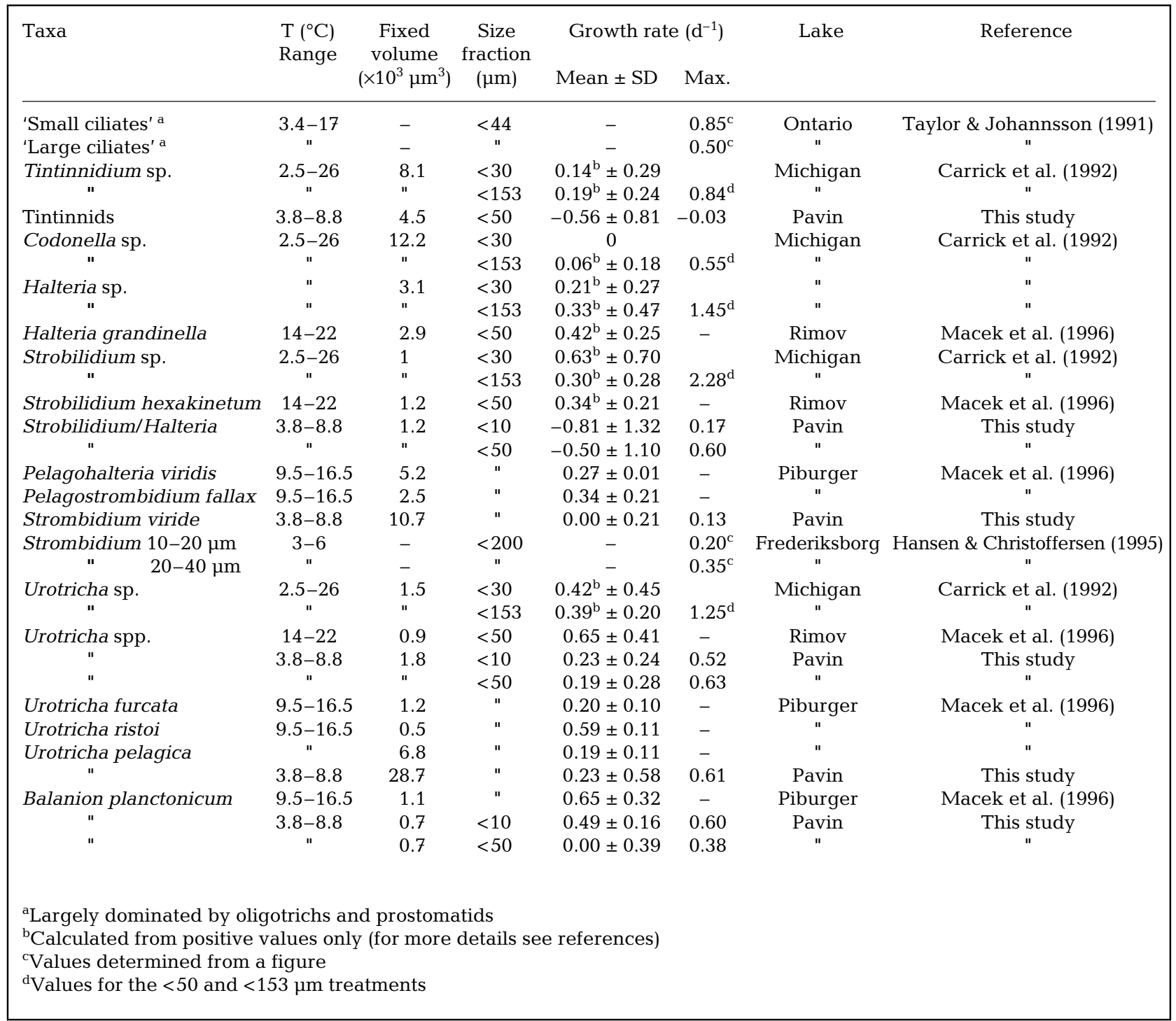




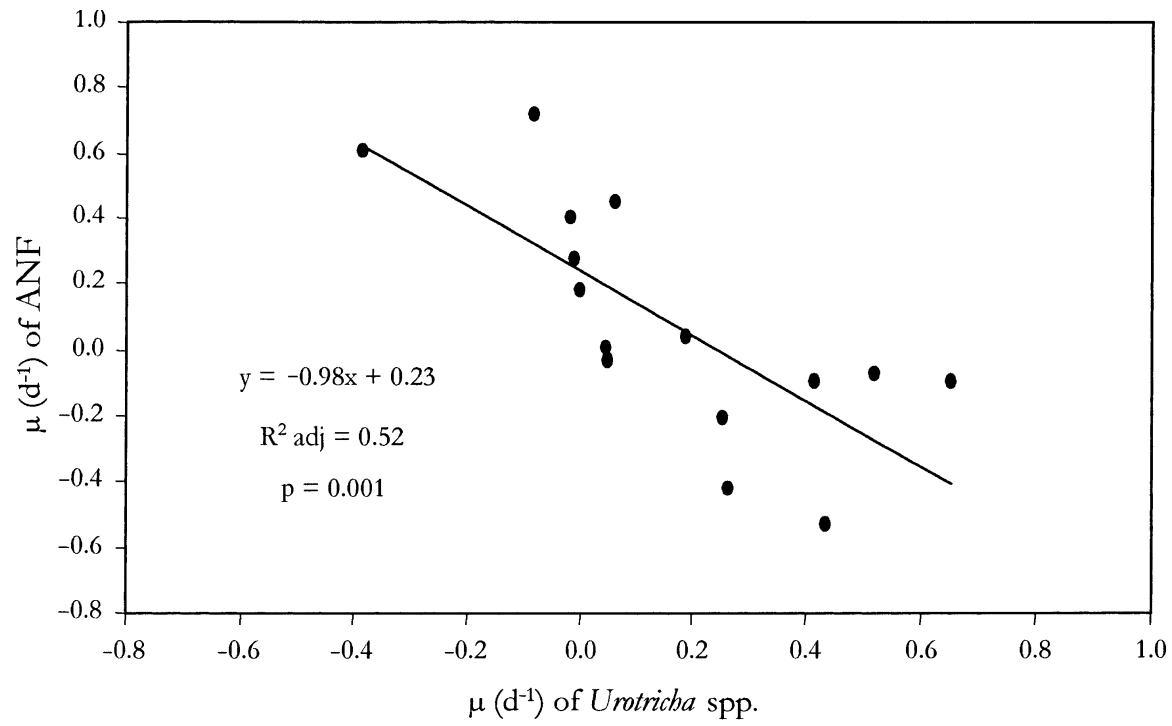

Fig. 5. Relationship between small Urotricha spp. and ANF growth rates across all treatments and all dates

growth rates of HNF in the $<10 \mu \mathrm{m}$ fraction were significantly higher than in the $<50 \mu \mathrm{m}$ fraction whereas no difference was recorded for ANF. This demonstrates 2 phenomena. Firstly, HNF were subjected to high predation by large-size ciliates, unlike $\mathrm{ANF}$, and secondly, the impact of small ciliates in the $<10 \mu \mathrm{m}$ fraction was greater on ANF than on HNF. This latter phenomenon was confirmed by the strong negative correlation between the growth rates of small Urotricha spp. and ANF in all of the fractions studied (Fig. 5), whereas no significant relation was recorded between the growth rates of HNF and those of the small ciliates. We thus confirmed the hypothesis that small Urotricha is a very important nanoalgivore in lacustrine pelagic environments (Weisse et al. 1990, Sommaruga \& Psenner 1993) whereas its predatory activity on picoplankton may be very low (Šimek et al. 1995).

Our results suggest that Cyclops abyssorum prealpinus, the dominant metazooplankton species, had a preponderant impact on large-size ciliates and, apparently, no effect on Gymnodinium uberrimum (Table 1), the dominant phytoplankton species. Strong effects on large-sized ciliates by cyclopoid copepods have also been reported from an in situ bioassay experiment (Wiackowski et al. 1994). By assuming that the differ- ence between the growth rates in the chambers without $(<50 \mu \mathrm{m})$ and with metazooplankton (UF fraction) reflected the mortality caused by metazooplankton grazing, we can calculate the clearance rate for Cyclops abyssorum prealpinus by dividing this mortality by the abundance of the metazooplankton species. The estimated values for all our measurements varied from 0.1 to $8.5 \mathrm{ml}$ ind..$^{-1} \mathrm{~h}^{-1}$ (mean $=2.6$ $\mathrm{ml}$ ind..$^{-1} \mathrm{~h}^{-1}$ ) and were much higher most of the time than those reported in the laboratory conditions at $18^{\circ} \mathrm{C}$ by Wickham (1995) for Cyclops abyssorum and Cyclops kolensis consuming ciliates of the same size and at densities close to those in our experiments. Moreover, the mortality rates of largesize ciliates estimated in our experiments were often greater than $1.0 \mathrm{~d}^{-1}$ whereas the mortalities estimated in the laboratory at similar metazooplankton and ciliate densities at $20^{\circ} \mathrm{C}$ were often lower than $0.5 \mathrm{~d}^{-1}$ (Jack \& Gilbert 1997). Our results further indicate that the greater the decrease in the numbers of large-size ciliates during filtration, the higher their growth rates (Fig. 6), suggesting that a large part of the mortality of large ciliates could therefore result from intense competition for access to food and/or predation within the large-size ciliate community. This artefact could explain the inconsistency between the estimated values and pub-

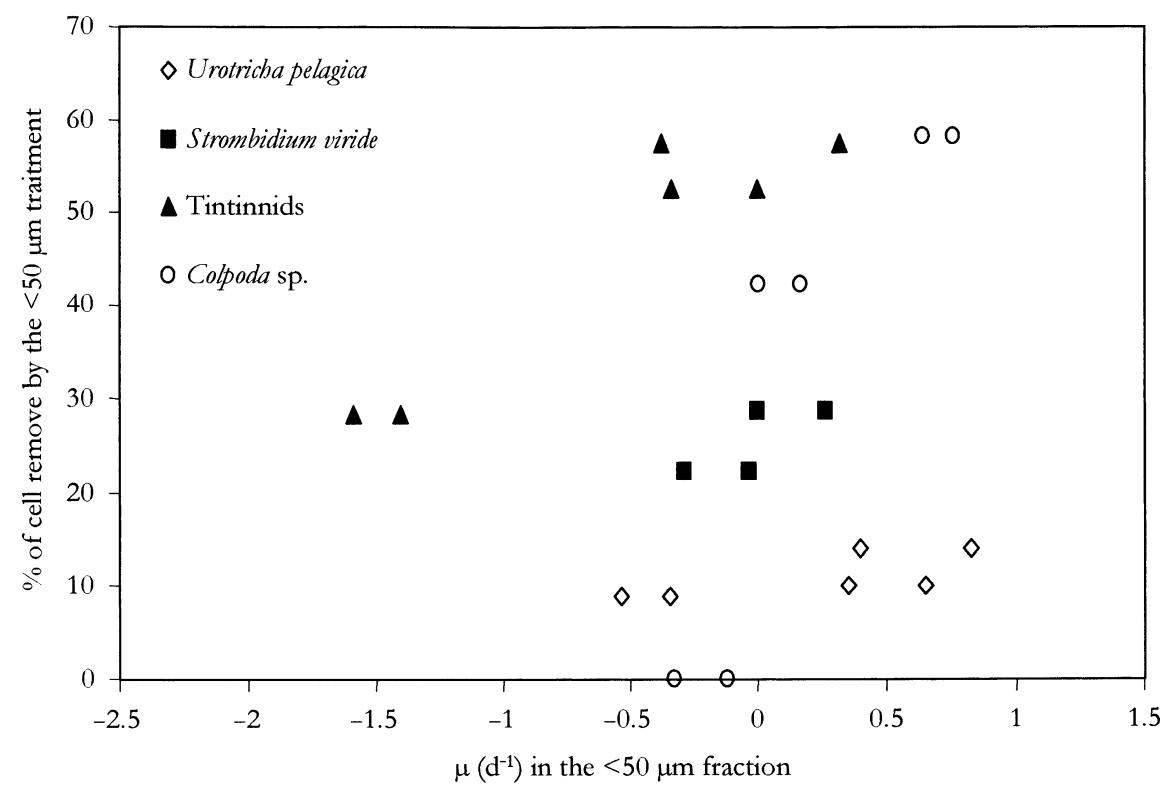

Fig. 6. Percentage of cells removed by the $<50 \mu \mathrm{m}$ treatment versus growth rates (duplicate values) in the $<50 \mu \mathrm{m}$ filtrate for large size ciliates 
lished values both for the clearance rate of Cyclops abyssorum prealpinus and the mortality rates of ciliates. Observations of population dynamics in spring in Lake Pavin also suggest that the metazoan zooplankton has only a slight impact on the communities of large-size ciliates; the apparent decrease in the densities of ciliates during April did not coincide with an increase in the metazooplankton abundance.

Our results also show that the presence of metazooplankton had no effect on the growth of nanoflagellates and small ciliates. However, if the effect of removing the metazooplankton is analysed for individual dates, the growth rates of HNF and small Urotricha spp. were significantly higher in the $<50 \mu \mathrm{m}$ fraction than in the unfiltered fraction on the last 2 sampling dates (see Fig. 3, for HNF: $F=63.61, p=0.001$, for small Urotricha spp.: $F=11.61, \mathrm{p}=0.02)$, whereas the effect on the growth of large ciliates (represented exclusively by Strombidium viride on the last 2 sampling dates, Fig. 3) was not statistically significant. Our experiments in diffusion chambers thus suggest (1) that large-size ciliates may be able to efficiently transfer energy between the HNF community and metazooplankton and (2) that small-sized Urotricha may act as an essential trophic link between ANF and metazooplankton. In addition, fractionation of pelagic samples may result in a substantial reduction of competition among protozoa assemblages, thereby increasing the potential growth of the unaffected individuals.

\section{LITERATURE CITED}

Amblard C, Bourdier G (1990) The spring bloom of the diatom Melosira italica ssp. subarctica in Lake Pavin: biochemical, energetic and metabolic aspects during sedimentation. J Plankton Res 12:645-660

Amblard C, Rachiq S, Bourdier G (1992) Photolithotrophy, photoheterotrophy and chemoheterotrophy during spring phytoplankton development (Lake Pavin). Microb Ecol 24: 109-123

Beaver JR, Crisman TL (1989) The role of ciliated protozoa in pelagic freshwater ecosystems. Microb Ecol 17:11-136

Bloem J, Bär-Gilissen M-JB, Cappenberg TE (1986) Fixation, counting, and manipulation of heterotrophic nanoflagellates. Appl Environ Microbiol 52:1266-1272

Bourrelly P (1966) Les algues d'eau douce, Tome I: Les algues vertes. N. Boudée and Co, Paris

Bourrelly P (1968) Les algues d'eau douce, Tome II: Les algues jaunes et brunes. N. Boudée and $\mathrm{Co}$, Paris

Bourrelly P (1970) Les algues d'eau douce, Tome III: Les algues bleues et rouges. N. Boudée and Co, Paris

Burns CW, Gilbert JJ (1993) Predation on ciliates by freshwater calanoid copepods: rates of predation and relative vulnerabilities of prey. Freshw Biol 30:377-393

Caron DA (1983) Technique for enumeration of heterotrophic and phototrophic nanoplankton, using epifluorescence microscopy, and comparison with other procedures. Appl Environ Microbiol 13:203-208

Carrias JF, Amblard C, Bourdier G (1996) Protistan bacteriv- ory in an oligomesotrophic lake: importance of attached ciliates and flagellates. Microb Ecol 31:249-268

Carrias JF, Amblard C, Quiblier-Lloberas C, Bourdier G (1998a) Seasonal dynamics of free and attached heterotrophic nanoflagellates in an oligomesotrophic lake. Freshw Biol 39:101-111

Carrias JF, Amblard C, Bourdier G (1998b) Seasonal dynamics and vertical distribution of planktonic ciliates and their relationship to microbial resources in the oligomesotrophic Lake Pavin. Arch Hydrobiol 143:227-255

Carrick HJ, Fahnenstiel GL, Taylor WD (1992) Growth and production of planktonic protozoa in Lake Michigan: In situ versus in vitro comparisons and importance to food webs dynamics. Limnol Oceanogr 37:1221-1235

Chrzanowski TH, Šimek K (1993) Bacterial growth and losses due to bacterivory in a mesotrophic lake. J Plankton Res 15:771-785

Fenchel T (1987) Ecology of protozoa: the biology of freeliving phagotrophic protists. Science Tech Publishers, Madison, WI/Springer-Verlag, New York, p 197

Foissner W, Berger H (1996) A user-friendly guide to the ciliates (Protozoa, Ciliophora) commonly used by hydrobiologists as bioindicators in rivers, lakes, and waste waters, with notes on their ecology. Freshw Biol 35:375-482

Foissner W, Blatterer H, Berger H, Kohmann F (1991) Taxonomische und ökologische Revision der Ciliaten des Saprobiensystems, Band I. Cyrtophorida, Oligotrichida, Hypotrichida, Colpodea. Informationsberichte des Bayer. Landesamtes für Wasserwirtschaft, Heft 1/91, p 478

Foissner W, Berger H, Kohmann F (1992) Taxonomische und ökologische Revision der Ciliaten des Saprobiensystems, Band II. Peritrichida, Heterotrichida, Odontostomatida. Informationsberichte des Bayer. Landesamtes für Wasserwirtschaft, Heft 5/92

Foissner W, Berger H, Kohmann F (1994) Taxonomische und ökologische Revision der Ciliaten des Saprobiensystems, Band III. Hymenostomata, Prostomatida, Nassulida. Informationsberichte des Bayer. Landesamtes für Wasserwirtschaft, Heft 1/94, p 548

Foissner W, Blatterer H, Berger H, Kohmann F (1995) Taxonomische und ökologische Revision der Ciliaten des Saprobiensystems, Band IV. Gymnostomatea, Loxodes, Suctoria. Informationsberichte des Bayer. Landesamtes für Wasserwirtschaft, Heft 1/95

Gifford DJ (1991) The Protozoan-Metazoan trophic link in pelagial ecosystems. J Protozool 38:81-86

Hansen B, Christoffersen K (1995) Specific growth rates of heterotrophic plankton organisms in a eutrophic lake during a spring bloom. J Plankton Res 17:413-430

Jack JD, Gilbert JJ (1997) Effects of metazoan predators on ciliates in freshwater plankton communities. J Eukaryot Microbiol 44:194-199

Jürgens K (1994) Impact of Daphnia on planktonic microbial food webs. A review. Mar Microb Food Webs 8:295-324

Jürgens K, Skibbe O, Jeppesen E (1999) Impact of metazooplankton on the composition and population dynamics of planktonic ciliates in a shallow, hypertrophic lake. Aquat Microb Ecol 17:61-75

Laybourn-Parry J (1994) Seasonal successions of protozooplankton in freshwater ecosystems of different latitudes. Mar Microb Food Webs 8:145-162

Macek M, Šimek K, Pernthaler J, Vyhnalek V, Psenner R (1996) Growth rates of dominant planktonic ciliates in two freshwater bodies of different trophic degree. J Plankton Res 18:463-481

Montagnes DJS (1996) Growth responses of planktonic ciliates in the genera Strobilidium and Strombidium. Mar 
Ecol Prog Ser 130:241-254

Montagnes DJS, Lynn DH, Roff JC, Taylor WD (1988) The annual cycle of heterotrophic planktonic ciliates in the waters surrounding the Isles of Shoals, Gulf of Maine: an assessment of their trophic role. Mar Biol 99:21-30

Müller H (1991) Pseudobalanion planctonicum (Ciliophora, Prostomatida): ecological significance of an algivorous nanociliate in a deep mesoeutrophic lake. J Plankton Res 13:247-262

Müller H, Geller W (1993) Maximum growth rates of aquatic ciliated protozoa: the dependence on body size and temperature reconsidered. Arch Hydrobiol 126:315-327

Müller H, Weisse T (1994) Laboratory and field observations on the scuticociliate Histiobalantium from the pelagic zone of Lake Constance, FRG. J Plankton Res 16:391-401

Nagata T (1988) The microflagellate-picoplanton food linkage in the water column of Lake Biwa. Limnol Oceanogr 33:504-517

Prepas E (1978) Sugar-frosted Daphnia: an improved fixation technique for Cladocera. Limnol Oceanogr 23:557-559

Quiblier-Lloberas C, Bourdier G, Amblard C, Pepin D (1996) A qualitative study of zooplankton grazing in an oligomesotrophic lake using phytoplanktonic pigments as organic markers. Limnol Oceanogr 41:1767-1779

Rassoulzadegan F, Laval-Peuto M, Sheldon RW (1988) Partitioning of the food ration of marine ciliates between picoand nanoplankton. Hydrobiol 159:75-88

Riemann B, Christoffersen K (1993) Microbial trophodynamics in temperate lakes. Mar Microb Food Webs 7:69-100

Sanders RW, Wickham SA (1993) Planktonic protozoa and metazoa: predation, food quality and population control. Mar Microb Food Webs 7:197-223

Sanders RW, Porter KG, Bennett SJ, Debiase AE (1989) Seasonal patterns of bacterivory by flagellates, ciliates, rotifers, and cladocerans in a freshwater planktonic community. Limnol Oceanogr 34:673-687

Šimek K, Bobkova J, Macek M, Nemoda J, Psenner R (1995) Ciliates grazing on picoplankton in a eutrophic reservoir during summer phytoplankton maximum: a study at the species and community level. Limnol Oceanogr 40: $1077-1090$

Šimek K, Hartman P, Nedoma J, Pernthaler J, Springmann D, Vrba J, Psenner R (1997) Community structure, picoplankton grazing and zooplankton control of heterotrophic nanoflagellates in a eutrophic reservoir during summer

Editorial responsibility: Karel Simek, Česke Budëjovice, Czech Republic phytoplankton maximum. Aquat Microb Ecol 12:49-63

Šimek K, Jürgens $K$, Nedoma J, Comerma M, Armengol J (2000) Ecological role and bacterial grazing of Halteria spp.: small freshwater oligotrichs as dominant pelagic ciliate bacterivores. Aquat Microb Ecol 22:43-56

Sime-Ngando T, Hartmann HJ, Grolière CA (1990) rapid quantification of planktonic ciliates: comparison of improved live counting with other methods. Appl Environ Microbiol 56:2234-2242

Sommaruga R, Psenner R (1993) Nanociliates of the order Prostomatida: their relevance in the microbial food web of a mesotrophic lake. Aquat Sci 55:179-187

Stabell T (1996) Ciliate bacterivory in epilimnetic waters. Aquat Microb Ecol 10:265-272

Stockner JG, Klut ME, Cochlan WP (1990) Leaky filters: a warning to aquatic ecologists. Can J Fish Aquat Sci 47: $16-23$

Stoecker DK, Capuzzo J (1990) Predation on protozoa. Its importance to zooplankton. J Plankton Res 12:891-908

Taylor WD, Johannsson OE (1991) A comparison of estimates of productivity and consumption by zooplankton for planktonic ciliates in lake Ontario. J Plankton Res 13: 363-372

Thouvenot A, Richardot M, Debroas D, Devaux J (1999) Bacterivory of metazooplankton, ciliates and flagellates in a newly flooded reservoir. J Plankton Res 21:1659-1679

Vaqué D, Pace ML (1992) Grazing on bacteria by flagellates and cladocerans in lakes contrasting food-web structure. J Plankton Res 14:307-321

Weisse T (1991) The annual cycle of heterotrophic freshwater nanoflagellates: role of bottom-up versus top-down control. J Plankton Res 13:167-185

Weisse $\mathrm{T}$ (1997) Growth and production of heterotrophic nanoflagellates in a meso-eutrophic lake. J Plankton Res 19:703-722

Weisse T, Müller H, Pinto-Coelho RM, Schweizer A, Springmann D, Baldringer G (1990) Response of the microbial loop to the phytoplankton spring bloom in a large prealpine lake. Limnol Oceanogr 35:781-794

Wiackowski K, Brett MT, Goldman CR (1994) Differential effects of zooplankton species on ciliate community structure. Limnol Oceanogr 39:486-492

Wickham SA (1995) Cyclops predation on ciliates: speciesspecific differences and functional responses. J Plankton Res 17:1633-1646

Submitted: October 10, 2000; Accepted: February 16, 2001 Proofs received from author(s): May 4, 2001 